\title{
High tumour-associated macrophages infiltration is correlated with poor survival outcome in classical Hodgkin's lymphoma
}

\author{
Jaudah Al-Maghrabi ${ }^{1,3}$, Wafaey Gomaa*1,2, Zuhoor Al-Mansouri ${ }^{3}$, Mohamed El-Sayed ${ }^{4,6}$, Tawfiq El-Khodary ${ }^{5,7}$ \\ ${ }^{1}$ Department of Pathology, Faculty of Medicine, King Abdulaziz University, Jeddah, Saudi Arabia \\ ${ }^{2}$ Department of Pathology, Faculty of Medicine, Minia University, Al Minia, Egypt \\ ${ }^{3}$ Department of Pathology, King Faisal Specialist Hospital and Research Centre, Jeddah, Saudi Arabia \\ ${ }^{4}$ Department of Oncology, Radiation Oncology Section, King Faisal Specialist Hospital and Research Centre, Jeddah, Saudi \\ Arabia \\ ${ }^{5}$ Department of Oncology, Medical Oncology Section, King Faisal Specialist Hospital and Research Centre, Jeddah, Saudi Arabia \\ ${ }^{6}$ Department of Radiotherapy and Nuclear Medicine, National Cancer Institute, Cairo University, Cairo, Egypt \\ ${ }^{7}$ Oncology Centre, Mansoura University, El Mansoura, Egypt
}

Received: September 12, 2015

DOI: $10.5430 /$ jst.v6n1p9
Accepted: October 26, 2015

Online Published: November 15, 2015

\begin{abstract}
Background: Classical Hodgkin's lymphoma (cHL) represents the majority of HLs with a relatively good prognosis. In $20 \%$ of patients, primary treatment fails. Prediction of treatment failure is critical. A gene signature of tumour associated macrophages (TAM) correlated with response to treatment as CD68 positive TAM was found to be associated with shortened survival. We aim to investigate the relation CD68+TAM infiltration to patients' outcome.

Patients and Methods: Pathological materials of 115 patients with cHL were used. Clinical characteristics of patients were collected from the records. CD68 immunostaining was performed to determine the number of infiltrating TAM and subsequently followed by stratification of results. Results of CD68 immunostaining were statistically analysed to correlate the extent of CD68+ TAM infiltration with clinicopathological characteristics, treatment outcome, and patients' survival.

Results: High CD68+TAM infiltration was observed in more patients of cHL (96/115 of patients = 83.5\%). High CD68+TAM infiltration was associated with extranodal presentation $(P=.001)$, and higher stage $(P=.022)$. No associations with other clinicopathological parameters were found. High CD68+TAM infiltration was not found to be an independent predictor of treatment outcome. High CD68+TAM infiltration correlated with disease free survival (DFS) $(\log$-rank $=4.505, P=.034)$ but not with disease specific survival (DSS) (log-rank $=1.371, P=.242$ ).

Conclusions: The results of our study support the adverse prognostic effect of high TAM in cHL. Technical standardisation of CD68 immunostaining is required to establish TAM infiltration as a prognostic predictor. Also in vivo and in vitro cHL models have to be established for proper understanding of the role of CD68 in modulating the TAM in cHL.
\end{abstract}

Key Words: Classical Hodgkin's lymphoma, CD68, Tumour-associated macrophages, Outcome

\footnotetext{
*Correspondence: Wafaey Gomaa; Email: wafgom@mu.edu.eg; Address: Department of Pathology, King Abdulaziz University, P.O. Box 80205, Jeddah 21589, Saudi Arabia.
} 


\section{INTRODUCTION}

Hodgkin's lymphoma (HL) represents around 30\% of lymphomas and is composed of two different disease categories; nodular lymphocyte-predominant HL and classical HL (cHL). cHL represents nearly $95 \%$ of HLs. ${ }^{[1-3]}$ cHL has a relatively good prognosis and with current chemotherapeutic and radiotherapeutic regimens, patients cure can be achieved in $80 \%$ of cases. The remaining $20 \%$, patients may be refractory to primary treatment or show relapse after remission. Also, $90 \%$ of untreated patients die 2-3 years. ${ }^{[1,4,5]}$ Accordingly, identification of patients with treatment failure or relapse is currently a challenge. ${ }^{[6]}$ The international Prognostic Score (IPS) is widely used as for prognosis, it is reproducible and consistent, however; it cannot reliably identify treatment failure. ${ }^{[7]}$ In addition, other clinical parameters cannot predict the majority of standard therapy failure. So, novel and robust biological markers for prediction of primary treatment outcome in disease stages are critical. Furthermore, cHL molecular model is needed to improve our understanding the pathogenesis and biology of treatment failure. ${ }^{[8,9]}$

The histological hallmark in cHL is the malignant Hodgkin's and Reed Sternberg (HRS) cells. ${ }^{[10]}$ HRS cells represent a small fraction of the tumour and secrete cytokines responsible for recruiting the large number of reactive non-neoplastic cells including T cells, B lymphocytes, macrophages, neutrophils, eosinophils, plasma cells, mast cells, and fibroblasts, which constitute the tumour microenvironment. ${ }^{[3]}$ The prognostic impact tumour microenvironment was studied. The presence of numerous tumour associated macrophages (TAM) in HL correlated with B symptoms and a poor response to therapy. ${ }^{[10-14]}$ Also, TAM had been associated with disease status in non-haematological malignancies. ${ }^{[15-17]}$ A gene signature of TAM associated with primary treatment failure in $\mathrm{cHL}$ and immunohistochemical detection of TAM was correlated with a shorter disease free survival (DFS). ${ }^{[18-20]}$ CD68 is a glycoprotein that is used as macrophage marker and also can be detected in other cells as dendritic cells, myeloid cells, fibroblasts, Langerhans cells and other cells. ${ }^{[21-24]}$ CD68 positive TAM in cHL gained an interest and was found to be associated with shorter disease specific survival (DSS). ${ }^{[19]}$

The aim of any research regarding TAM should be directed towards prediction of treatment outcome in $\mathrm{cHL}$ and applicability in clinical practice. We aim from the current study to confirm the relationship between CD68+TAM infiltration and clinical outcome in a subset of cHL patients treated with the standard chemotherapy and radiotherapy regimens.

\section{MATERIALS AND METHODS}

\subsection{Patients}

The study included paraffin wax blocks of tumours from 115 patients with cHL. Patients' histological materials were retrieved from the archive of the Department of Pathology at King Faisal Specialist Hospital and Research Centre, Jeddah, Saudi Arabia. Diagnosis was reviewed and confirmed according to the histological and immunostaining characteristics defined in the World Health Organisation classification. ${ }^{[10]}$ Clinical characteristics of patients were collected from the records and are listed in Table 1. IPS was calculated as previously described. ${ }^{[7]}$ Patients were categorised as lowrisk if the IPS was less than three and high-risk if IP was three or more. Staging of the disease was done according to the Cotswolds modification of the Ann Arbor classification. ${ }^{[25]}$ The patients were treated initially with $4-8$ cycles of chemotherapy and when indicated, followed by involved field of radiotherapy for patients with limited disease or initially bulky mass. Primary treatment success was defined as the absence of progression or relapse. Primary treatment failure was defined if cHL had progressed at any time after the initiation of therapy. All patients' samples and related data analyses were performed after approval by the ethical review board of King Faisal Specialist Hospital and Research Centre.

\subsection{CD68 immunostaining}

Four $\mu \mathrm{m}$ sections were sectioned from paraffin blocks of tumours and mounted on ready to used positively charged slides (Leica Microsystems Plus Slides, Menzel, Braunschweig, Germany). Immunostaining was done in BenchMark immunostainer (BenchMark XT, Ventana ${ }^{\mathrm{R}}$ Medical systems Inc., Tucson, AZ, USA) according to the manufacturer's instructions. Pre-treatment was done using CC1 (prediluted cell conditioning solution) for 30 minutes. Monoclonal mouse anti-human CD68 primary antibody (clone PG-M1, dilution1:100, Dako, Glostrup Denmark) was used. Anti-CD68 antibody was incubated with tissues for $32 \mathrm{~min}$ utes at $37^{\circ} \mathrm{C}$. Ventana ${ }^{\mathrm{R}}$ I-view DAB detection kit was used according to kit manufacturer instructions. Subsequently, slides were washed, counterstained with Mayer's haematoxylin, and mounted. Negative control (by substitution of primary antibody with Tris-buffered saline) was used. Positive control tissue form tonsil was used.

\subsection{Interpretation of CD68 immunostaining}

Areas containing tumour were analysed, and areas of fibrosis, necrosis, or reactive lymphoid tissue were avoided. TAMs exhibiting granular cytoplasmic staining were considered positive. Scoring of CD68 immunostaining in TAM was performed in HRS rich areas in each tumour section. 
Table 1. Demographic and Clinical Characteristics

\begin{tabular}{|c|c|c|}
\hline & & Number (\%) \\
\hline \multirow{2}{*}{ Sex } & Male & $72(62.6 \%)$ \\
\hline & Female & $43(37.4 \%)$ \\
\hline \multirow{2}{*}{$\begin{array}{l}\text { Age } \\
\text { (range: 7-80 years) }\end{array}$} & $\geq 45$ years & $91(79.1 \%)$ \\
\hline & $<45$ years & $24(20.9)$ \\
\hline \multirow{4}{*}{ Histological subtypes } & NSHL & $89(77.4 \%)$ \\
\hline & MCHL & $17(14.8 \%)$ \\
\hline & LRHL & $9(7.8 \%)$ \\
\hline & LDHL & $0(0 \%)$ \\
\hline \multirow{2}{*}{$\begin{array}{l}\text { Extranodal disease } \\
\text { presentation }\end{array}$} & Present & $2(1.7 \%)$ \\
\hline & Absent & $113(98.3 \%)$ \\
\hline \multirow{2}{*}{ Constitutional symptoms } & Present & $79(68.7 \%)$ \\
\hline & Absent & $36(31.3 \%)$ \\
\hline \multirow{2}{*}{ Spleen involvement } & Present & $24(20.9 \%)$ \\
\hline & Absent & $91(79.1 \%)$ \\
\hline \multirow{2}{*}{ Bulky disease } & $\geq 10 \mathrm{~cm}$ & $12(10.4 \%)$ \\
\hline & $<10 \mathrm{~cm}$ & $103(89.6 \%)$ \\
\hline \multirow{2}{*}{ IPS } & $0-2$ (low risk) & $61(53 \%)$ \\
\hline & $\geq 3$ (high risk) & $54(47 \%)$ \\
\hline \multirow{4}{*}{ Ann Arbor stage } & I & $5(4.3 \%)$ \\
\hline & II & $42(36.5 \%)$ \\
\hline & III & $32(27.8 \%)$ \\
\hline & IV & $36(31.3 \%)$ \\
\hline \multirow{2}{*}{$\begin{array}{l}\text { Primary chemotherapy } \\
\text { treatment }\end{array}$} & Given & $113(98.3 \%)$ \\
\hline & Not given & $2(1.7 \%)$ \\
\hline \multirow{3}{*}{ Type of chemotherapy } & ABVD & $103(89.6 \%)$ \\
\hline & Others & $10(8.7 \%)$ \\
\hline & Not given & $2(1.7 \%)$ \\
\hline \multirow{2}{*}{$\begin{array}{l}\text { Primary radiotherapy } \\
\text { treatment }\end{array}$} & Given & $51(44.3 \%)$ \\
\hline & Not given & $64(55.7 \%)$ \\
\hline \multirow{2}{*}{$\begin{array}{l}\text { Primary treatment } \\
\text { outcome (first relapse) }\end{array}$} & No relapse & $61(53 \%)$ \\
\hline & Relapse & $54(47 \%)$ \\
\hline \multirow{2}{*}{$\begin{array}{l}\text { Bone marrow } \\
\text { transplantation (in } 54 \\
\text { relapsing patients) }\end{array}$} & Done & $26(48.1 \%)$ \\
\hline & Not done & $28(51.9 \%)$ \\
\hline \multirow{3}{*}{$\begin{array}{l}\text { Second relapse after } \\
\text { salvage treatment (bone } \\
\text { marrow transplanted } \\
\text { patients). } n=26\end{array}$} & Present & $8(30.8 \%)$ \\
\hline & Absent & $18(69.2 \%)$ \\
\hline & Alive without disease & $81(70.4 \%)$ \\
\hline \multirow[t]{2}{*}{ Status } & Alive with disease & $15(13 \%)$ \\
\hline & Dead & $19(16.5 \%)$ \\
\hline
\end{tabular}

Note. IPS $=$ International Prognostic Score; $\mathrm{ABVD}=\left(\right.$ Adriamycin $^{\circledR}$ [doxorubicin], bleomycin, vinblastine and dacarbazine); NSHL $=$ Nodular Sclerosis Hodgkin's Lymphoma; $\mathrm{MCHL}=$ Mixed Cellularity HL; LRHL= Lymphocyte Rich HL; LDHL= Lymphocyte Depletion HL.
The percentage of CD68-positive TAM was calculated against the overall cellular component in each section. The percentage of positivity was classified into four scores; \{score 1$\}<5 \%$ positive cells, \{score 2$\} 5 \%-25 \%$ positive cells, \{score 3$\} 26 \%-50 \%$ positive cells, and $\{$ score 4$\}>$ $50 \%$ positive cells. ${ }^{[16,26]}$ We have used a $25 \%$ cut-off point to stratify each result as low CD68+ TAM infiltration (scores 1 and 2) and high CD68+ TAM infiltration (scores 3 and 4).

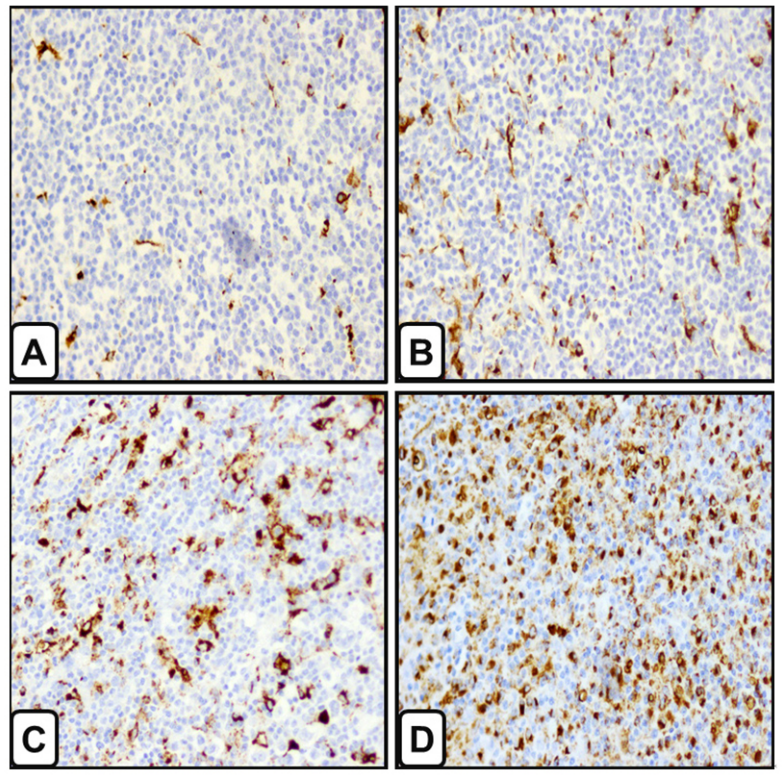

Figure 1. Immunostaining of CD68 in classical Hodgkin's lymphoma. Representative sections are shown from different histological subtypes. A: Section representing CD68 immunostaining in less than 5\% of macrophages. B: Section representing CD68 immunostaining from 5\%-25\%. C: Section representing CD68 immunostaining from $26 \%-50 \%$ of macrophages. D: Section representing CD68 immunostaining in more than $50 \%$ of macrophages. Original magnification used was $100 \times$. Immunostaining labelling was done using anti-CD68 antibody, diaminobenzidine as the chromogen, and haematoxylin as counterstain.

\subsection{Statistical analysis}

Difference of CD68+ TAM infiltration in two groups of patients was tested by Mann Whitney test and between three groups of patients by the Kruskal-Wallis. Wilcoxon signed rank test was used to compare differences between two related groups of paired variables. Binary logistic regression analysis was used to predict treatment outcome in relation CD68+ TAM infiltration and IPS. Estimated odds ratio exponential (B), 95\% confidence interval (CI) for exp (B), and significance denoted for each analysis. The Kaplan-Meier procedure was used to calculate DFS and DSS probabilities. The Log Rank was used to compare the difference between survivals. 
Table 2. Correlation of CD68+ TAM infiltration in relation to clinicopathological characteristics

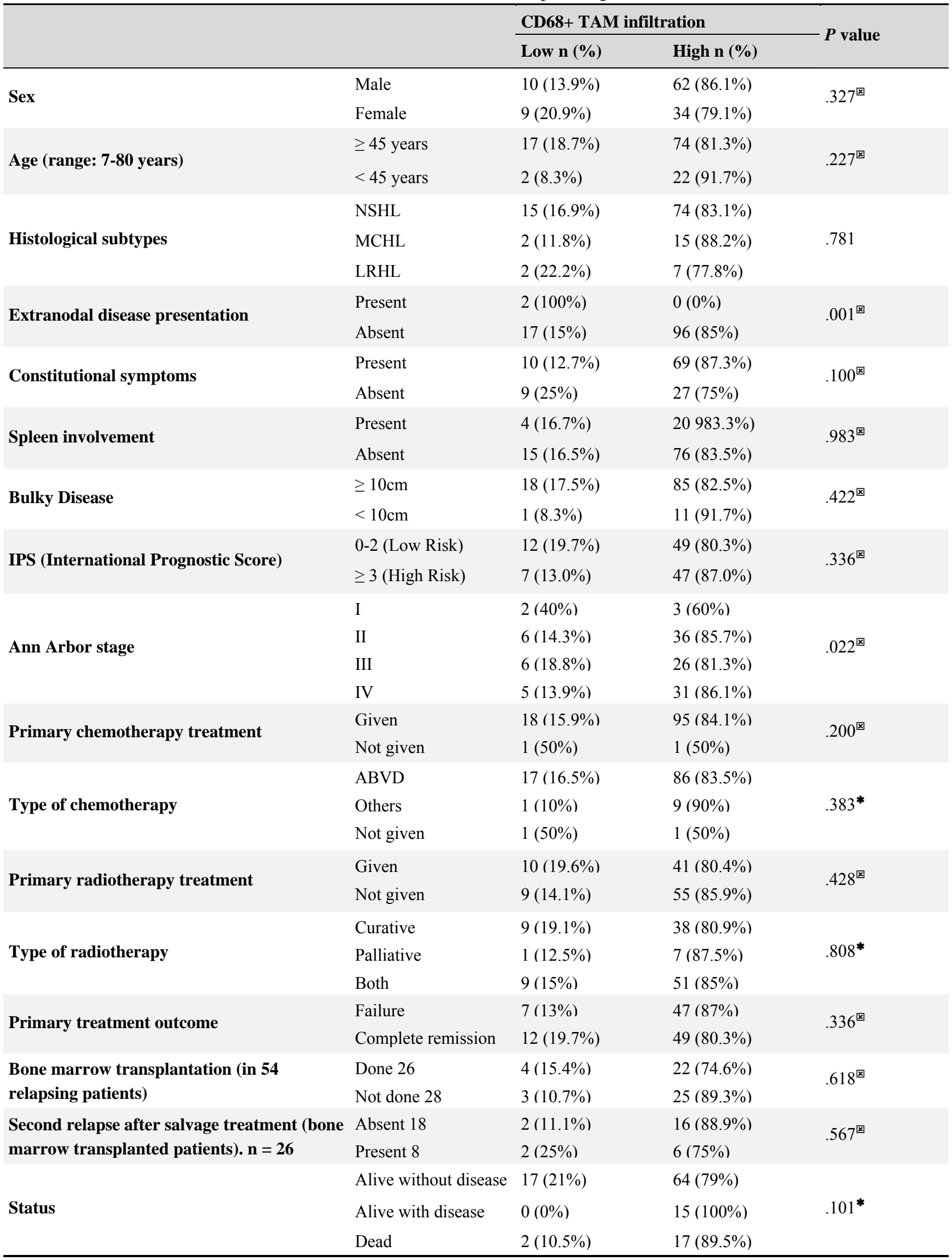


For DFS, time was calculated from the date of diagnosis to the appearance of disease relapse, or progression (or date last seen disease-free). For DSS, time was calculated as the time from diagnosis to the date of death from lymphoma, its treatment, or last contact. Patients were censored if, died of unrelated causes or discontinued treatment for any reason. Statistical procedures were performed using SPSS ${ }^{\circledR}$ Release 16.0. Statistical significance was determined at $P$ value of $\leq$ .05 and was 2 -sided.

\section{Results}

\subsection{CD68 immunostaining}

Granular cytoplasmic CD68 immunostaining was observed in TAM as shown in Figure 1 with clean background. Low CD68+TAM infiltration was observed in a lower number of tumours $(\mathrm{n}=19,16.5 \%)$ than high CD68+TAM $(\mathrm{n}=96$, $83.5 \%)(P<.001)$.

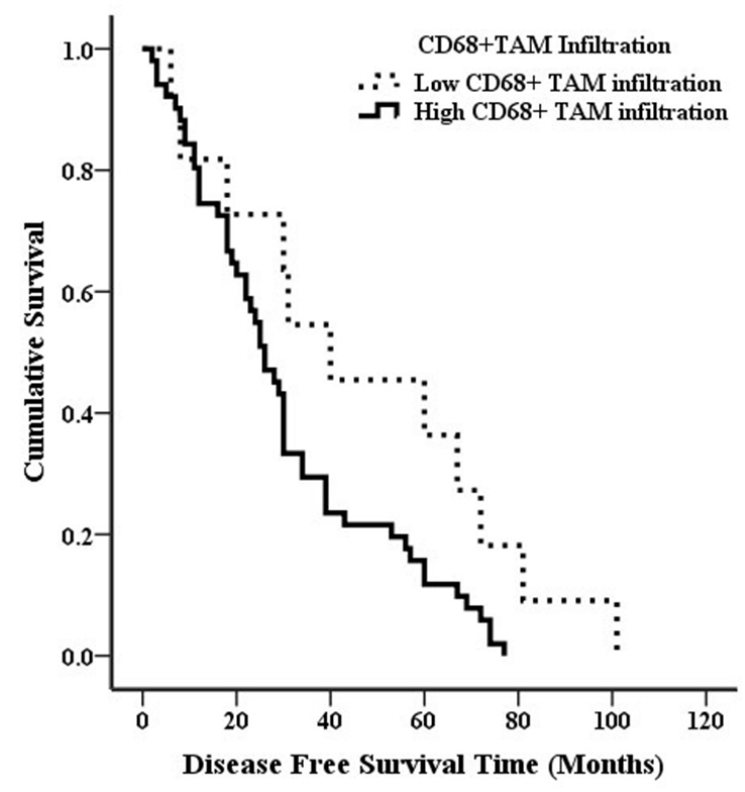

Figure 2. Kaplan Meier Disease-Free Survival (DFS) curve in relation to CD68+TAM infiltration (log-rank $=4.505, P=$ .034). Patients with low CD+68 TAM infiltration had longer survival than those showed high CD68+ TAM infiltration. Cut-off point used was $25 \%$.

\subsection{Association of CD68+ TAM infiltration with clinico- pathological features}

High CD68+TAM infiltration was significantly associated with extranodal presentation of $\mathrm{cHL}(P=.001)$ and higher stages tumours (stage 2, 3, and 4$)$ than in stage $1(P=.022)$. However, there was no significant association of CD68+ TAM infiltration with the rest of clinicopathological parameters. The association between CD68+ TAM infiltration and clinicopathological features are listed in Table 2.

Published by Sciedu Press
3.3 Correlation of CD68+ TAM infiltration with patient outcome (relapse or death)

Logistic regression analysis showed that CD68+ TAM infiltration was not an independent predictor of primary treatment outcome $(P=.337, \operatorname{Exp}(\mathrm{B})=1.644, \mathrm{CI}=0.596-4.535)$. Also, the IPS was not found to be an independent predictor of treatment outcome $(P=.174, \operatorname{Exp}(\mathrm{B})=1.670[\mathrm{CI}=$ $0.798-3.498]$ ). In survival analysis, there was a significant correlation between high CD68+ TAM infiltration and DFS (log-rank $=4.505, P=.034$ ). Survival curve is shown in Figure 2. However, there is no significant correlation between high CD68+ TAM infiltration and DSS (log-rank $=1.371, P$ $=.242$ ). Survival curve is shown in Figure 3 .

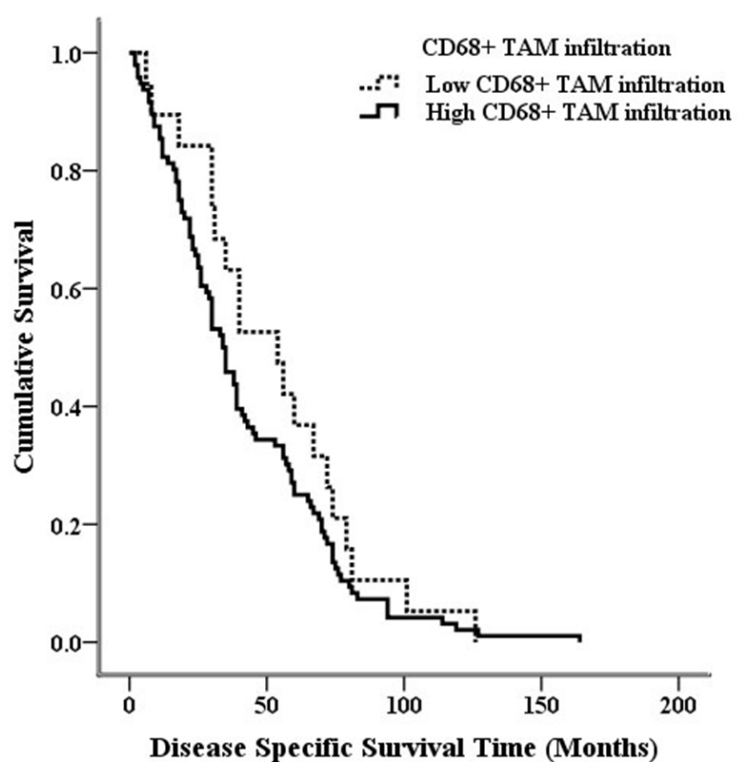

Figure 3. Kaplan Meier Disease-Specific Survival (DSS) curve in relation to CD68+TAM infiltration (log-rank = $1.371, P=.242$ ). There was no significant difference in survival probabilities. Cut-off point used was $25 \%$.

\section{Discussion}

The cellular microenvironment plays an important role in the pathogenesis of HL. ${ }^{[11,19,27,28]} \mathrm{cHL}$ microenvironment is modulated by cytokines and chemokines produced by HRS cells. ${ }^{[29]}$ The non-neoplastic cells are suggested to have a strong contribution to the biological behaviour of HL as well as prediction of treatment outcome. ${ }^{[19,30]}$ Immunohistochemical typing of microenvironment cells is increasing to understand the biology of $\mathrm{cHL}$ and to identify novel prognostic and therapeutic targets. ${ }^{[27]}$ Gene expression profiling studies have evidenced an adverse outcome in patients with the macrophage gene signature. ${ }^{[19,31-33]}$ The most common marker used for immunohistochemical detection of TAMs is CD68, which is expressed in a wide range of monocytes/macrophages and dendritic cells. ${ }^{[23,24]}$ 
Table 3. Studies using CD68 immunostaining in evaluation of TAM in cHL

\begin{tabular}{|c|c|c|c|c|c|c|c|}
\hline SN & Author (s) & Year & $\begin{array}{l}\text { Number of } \\
\text { cases }\end{array}$ & $\begin{array}{l}\text { Antibody } \\
\text { Clone }\end{array}$ & Scoring Method & Cut-off point & Results (High CD68) \\
\hline 1 & Steidl et al. ${ }^{[19]}$ & 2010 & 166 & KP1 & Manual Visual & $5 \%$ & $\begin{array}{l}\text { Associated with poor DFS and } \\
\text { DSS }\end{array}$ \\
\hline 2 & Yoon et al. ${ }^{[36]}$ & 2010 & 144 & KP1 & Manual Visual & $20 \%$ & $\begin{array}{l}\text { Associated with poor DFS, } \\
\text { DSS, OS }\end{array}$ \\
\hline 3 & Tzankov et al. ${ }^{[42]}$ & 2010 & 105 & PG-M1 & Manual Visual & $>0.82 \%$ & Associated with poor OS \\
\hline 4 & Zaki et al. ${ }^{[43]}$ & 2011 & 82 & PG-M1 & Manual Visual & Median & Associated with poor OS \\
\hline 5 & Jakovic et al. ${ }^{[37]}$ & 2011 & 52 & PG-M1 & Manual Visual & $25 \%$ & $\begin{array}{l}\text { Associated with poor DFS \& } \\
\text { OS }\end{array}$ \\
\hline 6 & Kamper et al. ${ }^{[41]}$ & 2011 & 288 & KP1 & Computer assisted & $7.8 \%$ & $\begin{array}{l}\text { Associated with poor DFS \& } \\
\text { OS }\end{array}$ \\
\hline 7 & Harris et al. ${ }^{[40]}$ & 2012 & 44 & KP1 & Manual Visual & $\begin{array}{l}<5 \% \sim 5 \%-25 \% \\
\sim>25 \%\end{array}$ & $\begin{array}{l}\text { Not associated with clinical } \\
\text { outcome }\end{array}$ \\
\hline 8 & $\begin{array}{l}\text { Sanchez-Espiridion } \\
\text { et al. }{ }^{[13]}\end{array}$ & 2012 & $226 / 103^{*}$ & KP1/ PG-M1 & Manual Visual & $\begin{array}{l}5 \%, 25 \% \text { and } \\
75 \%\end{array}$ & Associated with DSS \\
\hline 9 & Barros et al. ${ }^{[50]}$ & 2012 & 95 & PG-M1 & Computer assisted & $25 \%$ & $\begin{array}{l}\text { Not associated with clinical } \\
\text { outcome }\end{array}$ \\
\hline 10 & Azambuja et al. ${ }^{[16]}$ & 2012 & 265 & KP1 & Manual Visual & $\begin{array}{l}\text { Two cut-off } \\
5 \% \text { and } 25 \%\end{array}$ & $\begin{array}{l}\text { Not associated with clinical } \\
\text { outcome }\end{array}$ \\
\hline 11 & Tan et al. ${ }^{[5]}$ & 2012 & 247 & KP1 & $\begin{array}{l}\text { Computer assisted } \\
\text { (Aperio) }\end{array}$ & $12.7 \%$ & $\begin{array}{l}\text { Associated with poor DFS \& } \\
\text { OS }\end{array}$ \\
\hline 12 & Greaves et al. ${ }^{[44]}$ & 2013 & 122 & KP1 & Computer assisted & $\begin{array}{l}<5 \% \\
5-15 \% \\
>15 \%\end{array}$ & Associated with poor OS \\
\hline 13 & Gupta et al. ${ }^{[26]}$ & 2013 & 96 & KP1 & Manual Visual & $\begin{array}{l}<5 \% \sim 5 \%-25 \% \\
\sim 26 \%-50 \% \sim \\
>50 \%\end{array}$ & $\begin{array}{l}\text { Not associated with clinical } \\
\text { outcome }\end{array}$ \\
\hline 14 & Deau et al. ${ }^{[38]}$ & 2013 & 59 & KP1 & Manual Visual & $25 \%$ & $\begin{array}{l}\text { Associated with poor PFS } \\
\text { Associated with refractory and } \\
\text { early relapsed patients }\end{array}$ \\
\hline 15 & Panico et al. ${ }^{[35]}$ & 2013 & 154 & KP1 & Manual Visual & $30 \%$ or more & $\begin{array}{l}\text { Associated with poor PFS and } \\
\text { Short OS }\end{array}$ \\
\hline 16 & Casulo et al. ${ }^{[45]}$ & 2013 & 81 & KP1 & Manual Visual & $30 \%$ & Associated with poor OS \\
\hline 17 & Kayal et al. ${ }^{[39]}$ & 2014 & 100 & CD68/G2 & Manual Visual & $25 \%$ & $\begin{array}{l}\text { Not associated with clinical } \\
\text { outcome }\end{array}$ \\
\hline 18 & Current study & 2014 & 115 & PG-M1 & Manual Visual & $25 \%$ & Associated with poor DFS \\
\hline
\end{tabular}

Note. Paediatric group; * Two different groups; Multicentre study. DFS: Disease free survival; DSS: Disease specific survival.

In the current study, CD68+ TAM infiltration is increased in CD68+ TAM infiltration. ${ }^{[5,36]}$ This may be related to the cHL. This result is similar to previous study ${ }^{[35,36]}$ However, difference in the cut-off point of scoring (see Table 3). In the others found no significant difference between low or high present study, there was no statistically significant associa- 
tion between high CD68+ TAM infiltration and most clinicopathological features (apart from extranodal presentation and high disease stages). Similar findings were reported in previous studies. ${ }^{[16,37-40]}$ Also high CD68 was not found to be independent predictor of primary treatment outcome. However, different studies reported different association of high CD68 with some clinicopathological findings as B symptoms, ${ }^{[38,41,42]}$ age, ${ }^{[35,41]}$ mixed cellularity subtype, ${ }^{[5,35,41-43]}$ primary treatment failure, ${ }^{[5,19,36,38]}$ male sex ${ }^{[35]}$ bulky disease, ${ }^{[35]}$ and IPS. ${ }^{[35,37,41]}$ In our study, there was association between high CD68+ TAM infiltration and higher disease stage similar to previous reports. ${ }^{[19,35,42,44]}$

In the present study, we demonstrated a positive correlation between high CD68+ TAM infiltration and shortened DFS but not DSS. Several studies (see Table 3) reported association of high CD68+ TAM infiltration with poor survival outcome using DFS, DSS, or overall survival (OS). Table 3 summarises 17 studies concerning the relation between CD68+ TAM infiltration and survival outcome. Different cut-off points were used and accordingly the results are different. While, most studies reported association between high CD68+ TAM infiltration and poor survival outcomes (DFS, ${ }^{[5,19,35-38,41]} \mathrm{DSS},{ }^{[13,19,36]}$ or OS), ${ }^{[5,35-37,41-45]}$ fewer studies found that there no relation between high levels of CD68+ TAM infiltration and outcome. ${ }^{[16,26,39,40]}$ The results from our study support the trend that higher CD68+ TAM infiltration in TAM can be used as a biological marker for stratification of patients with risk of adverse outcome.

Lack of reproducibility of immunohistochemistry results is a major drawback for application of predictive markers of lymphomas in clinical practice. ${ }^{[8,16,44,46]}$ The lack of reproducibility and inconsistency in immunohistochemistry may result from issues related to the clone of antibody used, the scoring of immunostaining including the cut-off point and using manual or visual methods of scoring. Intra-tumour heterogeneity may be also another factor. As shown in Table 3 , there are few discrepancies regarding relation of CD68+ TAM infiltration with outcome in $\mathrm{CHL}$. This may be related to difference in number of cases used, anti-CD68 clone, the scoring method, and the cut-off point. The vast majority of published studies concerning CD68 immunohistochemistry used either the clone KP1 or PGM1. In the present study, the more specific PGM1 anti-CD68 antibody was used. KP1 clone is widely used to detect CD68+ TAM infiltration. However, it has a lower specificity as it stains non-hematopoietic cells. ${ }^{[16,19,47-49]}$ The staining of such cells may complicate immunostaining results. PGM1 clone is more specific for in detecting CD68 positive TAM. ${ }^{[36,49]}$ Using PGM1 is recommended for more specific results and the clone should be standardised for routine detection of CD68 positive TAM.

Most studies in the literature have shown association between high TAM and poor outcome. However, there was a wide range of cut-off points of scoring for CD68 immunostaining. In the current study, $25 \%$ was used as a cut-off point and results were dichotomised into low and high CD68+ TAM infiltration. There is a wide range of cut-off points in the literature some are allocated on biased basis. The scoring also depends upon the clone as KP1 stains more cells in addition to macrophages. In about one third of recent publications the $25 \%$ cut-off point was used (see Table 3 ). However, there is also variability in the results from these studies as regards relation with patient's outcome. A gold standard for CD68 cut-off is required before transferring the use of CD68 in clinical practice.

As regards the method of scoring of CD68 immunostaining, our study used manual visual scoring. Few studies used a computer assisted methods to quantify immunohistochemical staining of CD68+ TAM infiltration. ${ }^{[5,41,50]}$ In two of them there was association between CD68+TAM infiltration and poor DFS and OS. ${ }^{[5,41]}$ In the third study, there was no association of CD68 with clinical outcome, probably due to small number of cases. ${ }^{[50]}$ There was no substantial difference between manual visual method and computer assisted method regarding the relation of CD68+ TAM infiltration with outcome. Challenges in using computer assisted methods include lack of availability in the routine diagnostic work, its labour intensiveness, and dependence on the overall visual volume. So, the semi-quantitative methods are more broadly applied in clinical practice.

In summary, the results of our study support the adverse prognostic effect of high TAM infiltration in cHL (namely extranodal presentation, higher stages of the disease and shortened DFS). However, the precise way in which CD68+ TAM infiltration positive macrophages affect cHL biology and treatment failure is not well understood. Technical standardisation in large series of cHL patients with comparable clinical stages regarding the cut-off point and scoring methodology is required before application of CD68+ TAM infiltration as a prognostic predictor in cHL. In vivo and in vitro cHL models have to be established for proper understanding of the role of CD68+ TAM infiltration in modulating the tumour microenvironment and possible link with HRS in cHL. Subsequently, large-scale validation and clinical application should be followed.

\section{CONFLicts OF INTEREST Disclosure}

The author declares that there is no conflict of interest statement. 


\section{REFERENCES}

[1] Diehl V, Stein H, Hummel M, et al. Hodgkin's lymphoma: biology and treatment strategies for primary, refractory, and relapsed disease. Hematology Am Soc Hematol Educ Program. 2003: 225-47. http://dx.doi.org/10.1182/asheducation-2003.1.225

[2] Mani H, Jaffe ES. Hodgkin lymphoma: an update on its biology with new insights into classification. Clin Lymphoma Myeloma. 2009; 9(3): 206-16. PMid:19525189. http://dx.doi.org/10.3816/C LM. 2009.n. 042

[3] Kuppers R. The biology of Hodgkin's lymphoma. Nat Rev Cancer 2009; 9(1): 15-27. PMid:19078975. http://dx.doi.org/10.10 $38 / \mathrm{nrc} 2542$

[4] Bjorkholm M, Axdorph U, Grimfors G, et al. Fixed versus responseadapted MOPP/ABVD chemotherapy in Hodgkin's disease. A prospective randomized trial. Ann Oncol. 1995; 6(9): 895-9. PMid:8624292.

[5] Tan KL, Scott DW, Hong F, et al. Tumor-associated macrophages predict inferior outcomes in classic Hodgkin lymphoma: a correlative study from the E2496 Intergroup trial. Blood. 2012; 120(16): 3280-7. PMid:22948049. http://dx.doi.org/10.1182/blood -2012-04-421057

[6] Canellos GP, Anderson JR, Propert KJ, et al. Chemotherapy of advanced Hodgkin's disease with MOPP, ABVD, or MOPP alternating with ABVD. N Engl J Med. 1992; 327(21): 1478-84. PMid:1383821 http://dx.doi.org/10.1056/NEJM199211193272102

[7] Hasenclever D, Diehl V. A prognostic score for advanced Hodgkin's disease. International Prognostic Factors Project on Advanced Hodgkin's Disease. N Engl J Med. 1998; 339(21): 1506-14. PMid:9819449. http://dx.doi.org/10.1056/NEJM199811193 392104

[8] Steidl C, Farinha P, Gascoyne RD. Macrophages predict treatment outcome in Hodgkin's lymphoma. Haematologica. 2011; 96(2): 186-9. PMid:21282720. http://dx.doi.org/10.3324/haemato 1.2010.033316

[9] Steidl C, Diepstra A, Lee T, et al. Gene expression profiling of microdissected Hodgkin Reed-Sternberg cells correlates with treatment outcome in classical Hodgkin lymphoma. Blood. 2012; 120(17): 3530-40. PMid:22955918. http://dx.doi .org/10.1182/blood -2012-06-439570

[10] Stein H, Delsol G, Pileri S. Classical Hodgkin lymphoma, Introduction in WHO Classification of Tumors of Hematopoietic and Lymphoid Tissues, 4th edition edn. Lyon, France: IARC. 2008.

[11] Ree HJ, Kadin ME. Macrophage-histiocytes in Hodgkin's disease. The relation of peanut-agglutinin-binding macrophage-histiocytes to clinicopathologic presentation and course of disease. Cancer. 1985; 56(2): 333-8. http://dx.doi.org/10.1002/1097-0142(1985 0715) $56: 2<333:$ : AID-CNCR2820560222>3.0.CO;2-0

[12] Coppleson LW, Rappaport H, Strum SB, et al. Analysis of the Rye classification of Hodgkin's disease. The prognostic significance of cellular composition. J Natl Cancer Inst. 1973; 51(2): 379-90. PMid:4765366.

[13] Sanchez-Espiridion B, Martin-Moreno AM, Montalban C, et al. Immunohistochemical markers for tumor associated macrophages and survival in advanced classical Hodgkin's lymphoma. Haematologica. 2012; 97(7): 1080-4. PMid:22315492.http://dx.doi.org/1 0.3324 /haematol.2011.055459

[14] Aldinucci D, Lorenzon D, Cattaruzza L, et al. Expression of CCR5 receptors on Reed-Sternberg cells and Hodgkin lymphoma cell lines: involvement of CCL5/Rantes in tumor cell growth and microenvironmental interactions. Int J Cancer. 2008; 122(4): 769-76. PMid:17935139. http://dx.doi.org/10.1002/ijc. 23119
[15] Chen JJ, Lin YC, Yao PL, et al. Tumor-associated macrophages: the double-edged sword in cancer progression. J Clin Oncol. 2005; 23(5): 953-64. PMid:15598976. http://dx.doi.org/10.1200/JC0.2 005.12 .172

[16] Azambuja D, Natkunam Y, Biasoli I, et al. Lack of association of tumor-associated macrophages with clinical outcome in patients with classical Hodgkin's lymphoma. Ann Oncol. 2012; 23(3): 73642. PMid:21602260. http://dx.doi.org/10.1093/annonc/md $\mathrm{r} 157$

[17] Qian BZ, Pollard JW. Macrophage diversity enhances tumor progression and metastasis. Cell. 2010; 141(1): 39-51. PMid:20371344. http://dx.doi.org/10.1016/j.cell.2010.03.014

[18] DeVita VT Jr. A breakthrough in Hodgkin's disease. Nat Rev Clin Oncol. 2010; 7(4): 179. PMid:20354537. http://dx.doi.org/1 $0.1038 / \mathrm{nrclinonc} .2010 .36$

[19] Steidl C, Lee T, Shah SP, et al. Tumor-associated macrophages and survival in classic Hodgkin's lymphoma. N Engl J Med. 2010; 362(10): 875-85. PMid:20220182. http://dx.doi.org/10.1056 /NEJMoa0905680

[20] Diehl V. Hematology. Are macrophages the bad guys in Hodgkin lymphoma? Nat Rev Clin Oncol. 2010; 7(6): 301-2. PMid:20517336. http://dx.doi.org/10.1038/nrclinonc.2010.71

[21] Fonseca JE, Edwards JC, Blades S, et al. Macrophage subpopulations in rheumatoid synovium: reduced CD163 expression in CD4+ T lymphocyte-rich microenvironments. Arthritis Rheum. 2002; 46(5): 1210-6. PMid:12115225. http://dx.doi.org/10.1002/art.1 0207

[22] Falini B, Flenghi L, Pileri S, et al. PG-M1: a new monoclonal antibody directed against a fixative-resistant epitope on the macrophagerestricted form of the CD68 molecule. Am J Pathol. 1993; 142(5): 1359-72. PMid:7684194

[23] Jensen TO, Schmidt H, Moller HJ, et al. Macrophage markers in serum and tumor have prognostic impact in American Joint Committee on Cancer stage I/II melanoma. J Clin Oncol. 2009; 27(20): 3330-7. PMid:19528371. http://dx.doi.org/10.1200/JC0.2 008.19 .9919

[24] Lau SK, Chu PG, Weiss LM. CD163: a specific marker of macrophages in paraffin-embedded tissue samples. Am J Clin Pathol. 2004; 122(5): 794-801. PMid:15491976. http://dx.doi.org/10. 1309/QHD6YFN81KQXUUH6

[25] Lister TA, Crowther D, Sutcliffe SB, et al. Report of a committee convened to discuss the evaluation and staging of patients with Hodgkin's disease: Cotswolds meeting. J Clin Oncol. 1989; 7(11): 1630-6. PMid:2809679.

[26] Gupta S, Yeh S, Chami R, et al. The prognostic impact of tumour-associated macrophages and Reed-Sternberg cells in paediatric Hodgkin lymphoma. Eur J Cancer. 2013; 49(15): 325561. PMid:23791542. http://dx.doi.org/10.1016/j.ejca. 20 13.05 .024

[27] Alvaro T, Lejeune M, Salvado MT, et al. Outcome in Hodgkin's lymphoma can be predicted from the presence of accompanying cytotoxic and regulatory T cells. Clin Cancer Res. 2005; 11(4): 1467-73. PMid:15746048. http://dx.doi.org/10.1158/1078-0432.CC R-04-1869

[28] Alvaro T, Lejeune M, Garcia JF, et al. Tumor-infiltrated immune response correlates with alterations in the apoptotic and cell cycle pathways in Hodgkin and Reed-Sternberg cells. Clin Cancer Res. 2008; 14(3): 685-91. PMid:18245527. http://dx.doi.org/10. 1158/1078-0432.CCR-07-1246

[29] Aldinucci D, Gloghini A, Pinto A, et al. The classical Hodgkin's lymphoma microenvironment and its role in promoting tumour growth 
and immune escape. J Pathol. 2010; 221(3): 248-63. PMid:20527019. http://dx.doi.org/10.1002/path.2711

[30] Lenz G, Wright G, Dave SS, et al. Stromal gene signatures in large-B-cell lymphomas. N Engl J Med. 2008; 359(22): 231323. PMid:19038878. http://dx.doi.org/10.1056/NEJMoa080 2885

[31] Sanchez-Aguilera A, Montalban C, de la Cueva P, et al. Tumor microenvironment and mitotic checkpoint are key factors in the outcome of classic Hodgkin lymphoma. Blood. 2006; 108(2): 6628. PMid:16551964. http://dx.doi.org/10.1182/blood-200 5-12-5125

[32] Chetaille B, Bertucci F, Finetti P, et al. Molecular profiling of classical Hodgkin lymphoma tissues uncovers variations in the tumor microenvironment and correlations with EBV infection and outcome. Blood. 2009; 113(12): 2765-3775. PMid:19096012. http: //dx.doi.org/10.1182/blood-2008-07-168096

[33] Devilard E, Bertucci F, Trempat P, et al. Gene expression profiling defines molecular subtypes of classical Hodgkin's disease. Oncogene. 2002; 21(19): 3095-3102. PMid:12082542. http://dx.doi.org $/ 10.1038 / \mathrm{sj}$. onc. 1205418

[34] Ma J, Liu L, Che G, et al. The M1 form of tumor-associated macrophages in non-small cell lung cancer is positively associated with survival time. BMC Cancer. 2010; 10: 112. PMid:20338029. http://dx.doi.org/10.1186/1471-2407-10-112

[35] Panico L, Ronconi F, Lepore M, et al. Prognostic role of tumorassociated macrophages and angiogenesis in classical Hodgkin lymphoma. Leuk Lymphoma. 2013; 54(11): 2418-25. PMid:23432688. http://dx.doi.org/10.3109/10428194.2013.778405

[36] Yoon DH, Koh YW, Kang HJ, et al. CD68 and CD163 as prognostic factors for Korean patients with Hodgkin lymphoma. Eur J Haematol. 2012; 88(4): 292-305. PMid:22044760. http://dx.doi.org/10. 1111/j.1600-0609.2011.01731.x

[37] Jakovic LR, Mihaljevic BS, Perunicic Jovanovic MD, et al. The prognostic relevance of tumor associated macrophages in advanced stage classical Hodgkin lymphoma. Leuk Lymphoma. 2011; 52(10): 1913-9. PMid:21663512. http://dx.doi.org/10.3109/10428 194.2011 .580026

[38] Deau B, Bachy E, Ribrag V, et al. Macrophage, mast cell and $\mathrm{T}$ lymphocyte infiltrations are independent predictive biomarkers of primary refractoriness or early relapse in classical Hodgkin lymphoma. Leuk Lymphoma. 2013; 54(1): 41-5. PMid:22667341. http://dx.doi.org/10.3109/10428194.2012.698274

[39] Kayal S, Mathur S, Karak AK, et al. CD68 tumor-associated macrophage marker is not prognostic of clinical outcome in classical Hodgkin lymphoma. Leuk Lymphoma. 2014. PMid:24067108. http://dx.doi.org/10.3109/10428194.2013.824079

[40] Harris JA, Jain S, Ren Q, et al. CD163 versus CD68 in tumor associated macrophages of classical Hodgkin lymphoma. Diagn Pathol.
2012; 7: 12. PMid:22289504. http://dx.doi.org/10.1186/1 746-1596-7-12

[41] Kamper P, Bendix K, Hamilton-Dutoit S, et al. Tumor-infiltrating macrophages correlate with adverse prognosis and Epstein-Barr virus status in classical Hodgkin's lymphoma. Haematologica. 2011; 96(2): 269-76. PMid:21071500. http://dx.doi.org/10.3324/haema tol.2010.031542

[42] Tzankov A, Matter MS, Dirnhofer S. Refined prognostic role of CD68-positive tumor macrophages in the context of the cellular micromilieu of classical Hodgkin lymphoma. Pathobiology. 2010; 77(6): 301-8. PMid:21266828. http://dx.doi.org/10.1159/0 00321567

[43] Zaki MA, Wada N, Ikeda J, et al. Prognostic implication of types of tumor-associated macrophages in Hodgkin lymphoma. Virchows Arch. 2011; 459(4): 361-6. PMid:21874508. http://dx.doi.org /10.1007/s00428-011-1140-8

[44] Greaves P, Clear A, Coutinho R, et al. Expression of FOXP3, CD68, and $\mathrm{CD} 20$ at diagnosis in the microenvironment of classical Hodgkin lymphoma is predictive of outcome. J Clin Oncol. 2013; 31(2): 25662. PMid:23045593. http://dx.doi.org/10.1200/JC0. 2011. 39.9881

[45] Casulo C, Arcila M, Bohn OL, et al. Tumor associated macrophages in relapsed and refractory Hodgkin lymphoma. Leuk Res. 2013; 37(9): 1178-83. PMid:23706570. http://dx.doi.org/10.1016 /j.leukres.2013.03.021

[46] de Jong D, Rosenwald A, Chhanabhai M, et al. Immunohistochemical prognostic markers in diffuse large B-cell lymphoma: validation of tissue microarray as a prerequisite for broad clinical applications-a study from the Lunenburg Lymphoma Biomarker Consortium. J Clin Oncol. 2007; 25(7): 805-12. PMid:17327602. http://dx.doi.org/10.1200/JC0.2006.09.4490

[47] Pulford KA, Sipos A, Cordell JL, et al. Distribution of the CD68 macrophage/myeloid associated antigen. Int Immunol. 1990; 2(10): 973-80. PMid:2078523. http://dx.doi.org/10.1093/intimm/ 2.10 .973

[48] Gottfried E, Kunz-Schughart LA, Weber A, et al. Expression of CD68 in non-myeloid cell types. Scand J Immunol. 2008; 67(5): 453-63. PMid:18405323. http://dx.doi.org/10.1111/j.136 5-3083.2008.02091. $x$

[49] Kunisch E, Fuhrmann R, Roth A, et al. Macrophage specificity of three anti-CD68 monoclonal antibodies (KP1, EBM11, and PGM1) widely used for immunohistochemistry and flow cytometry. Ann Rheum Dis. 2004; 63(7): 774-84. PMid:15194571. http: //dx.doi.org/10.1136/ard.2003.013029

[50] Barros MH, Hassan R, Niedobitek G. Tumor-associated macrophages in pediatric classical Hodgkin lymphoma: association with EpsteinBarr virus, lymphocyte subsets, and prognostic impact. Clin Cancer Res. 2012; 18(14): 3762-71. PMid:22645050. http://dx.doi.o $\mathrm{rg} / 10.1158 / 1078-0432$. CCR-12-0129 